\title{
Skin of the Thigh
}

National Cancer Institute

\section{Source}

National Cancer Institute. Skin of the Thigh. NCI Thesaurus. Code C150856.

The skin or integument covering the thigh. 